\title{
MARITIME ANTARCTIC LAKES AS SENTINELS OF CLIMATE CHANGE
}

\author{
A. CAMACHO ${ }^{1}$, C. ROCHERA ${ }^{1}$, J.A. VILLAESCUSA ${ }^{1}$, D. VELÁZQUEZ ${ }^{2}$, M. TORO ${ }^{3}$, E. RICO $^{4}$, E. FERNANDEZ- \\ VALIENTE $^{2}$, A. JUSTEL ${ }^{5}$, M. BAÑON ${ }^{6} \&$ A. QUESADA ${ }^{2}$ \\ ${ }^{1}$ Cavanilles Institute for Biodiversity and Evolutionary Biology, University of Valencia, Spain. \\ ${ }^{2}$ Department of Biology, Universidad Autónoma de Madrid, Spain. \\ ${ }^{3}$ Centro de Estudios Hidrográficos del CEDEX, Spain. \\ ${ }^{4}$ Department of Ecology, Universidad Autónoma de Madrid, Spain. \\ ${ }^{5}$ Department of Mathematics, Universidad Autónoma de Madrid, Spain. \\ ${ }^{6}$ Agencia Estatal de Meteorologia, Spain.
}

\begin{abstract}
Remote lakes, such as lakes from the Maritime Antarctica, can be used as sentinels of climate change, because they are mostly free of direct anthropogenic pressures, and they experience climate change as a main stressor capable of modifying the ecosystem structure and function. In this paper, the content of a lecture that has been presented at the First Conference of Lake Sustainability, which has been centred in our studies on lakes from Byers Peninsula (Maritime Antarctica), are summarized. These included physical, chemical and biological studies of these lakes and other freshwater ecosystems, which highlighted the relevance of biotic interactions for these ecosystems and its sensibility to temperature variations and to biological invasions, which is of relevance given the acute regional warming occurring during the last decades in the area, concomitant with the enhancement of dispersion of alien species linked to the increased presence of humans.

Keywords: Biological invasions, climate change, ecosystem modelling, environmental prognoses, Maritime Antarctica, regional warming, remote lakes, sensor systems, simple food webs, species interactions.
\end{abstract}

\section{INTRODUCTION}

Nowadays it is widely recognized that the world is entering a period of accelerated climate change [1], which is undoubtedly affecting lakes and other ecosystems. Changes in hydrology, biogeochemical cycles and the composition of biological communities and species interactions are, among others, expected to occur both at lake and catchment scales [2]. Because these climate-driving shifts are reflected in lake's ecological features, long-term monitoring allowing to reveal ecological trends, correlated with changes in climate, would permit the use of these ecosystems as good sensors (and sentinels) of whether something is occurring and, if so, the ecological consequences of these changes.

In a relatively recent Chapman Conference on 'Lakes and Reservoirs as Sentinels, Integrators, and Regulators of Climate Change', whose main contributions were published in 2009 in Limnology and Oceanography, a number of relevant limnologists highlighted the role of lakes as model ecosystems to study environmental changes. In an introductory paper of this issue, Williamson et al. [3] nicely illustrated how lakes are sentinels because they respond very rapidly to changes in solar irradiance, precipitation, wind, hydrology and a variety of atmospheric and terrestrial inputs. They also remarked the role of lakes as integrators of climate change, since lakes store signals of change in their sediments, which integrates changes in the own lake with the watershed and the surrounding terrestrial ecosystem and airshed. Moreover, lakes are also regulators of climate change by modulating biogeochemical and hydrological cycles and determining material exchanges.

Lakes can consequently be effective sentinels for climate change, because they are sensitive to climate, quick respond to change and integrate information about changes in the catchment. However, 
the efficacy of lakes as sentinels of climate change depends upon our understanding of internal lake processes [4], and a deep knowledge of lake functioning is required to reveal the effects of climate change on the different lake components and processes.

\section{LAKES AS SENSORS OF CLIMATE CHANGE: WHY REMOTENESS?}

\subsection{Remote lakes as sensors of climate change}

Nowadays, many lakes within the world are located in areas that are strongly anthropized, and because of this reason changes in their ecological features can be attributed to multiple stressors. It is quite unlikely that these lakes can be used to reveal climate-driving ecological trends currently occurring, as the separate effects of the different stressors cannot be determined. Remote lakes, located in low populated areas, or even isolated by geographical barriers, can also strongly experience the effects of global scale processes, such as climate change, acting at a regional scale of its watershed, and at a local scale directly on the own lake but are mostly free from other pressures. Consequently, remote lakes located in regions experiencing climate changes are good candidates to be used to discern the impact and effects of climate change from those of other anthropogenic pressures. Among these, mountain and polar lakes have mostly been used so far as sensors of these effects, as many of them are free of direct impacts from human activity but strongly experience the effects of climate-driven changes.

If we combine the sensitivity of mountain lake ecosystems to external forcing with their remoteness from areas of high human activity, it turns out that high mountain lakes can be used as sentinels and recorders of past and present environmental changes [5]. Because of this, they have been incorporated as model ecosystems in several collaborative research projects on global change $[6,7]$. Even though they are located in remote areas, many of the studied lakes are influenced by the circulation of air masses that are somewhat affected by atmospheric pollution, and they still suffer the consequences of air pollution by acid deposition, trace metals, and trace organic compounds, which can interplay with the effects of climate change. There is evidence, for example, that even the most remote lakes in Europe contain atmospherically transported pollutants [7].

Polar lakes, such as High Arctic lakes, which have experienced several decades of rapid environmental change with warming rates well above the global average, have also been used as sentinels of climate change [8]. Compared with the abovementioned European mountain lakes, remote polar lakes have the advantage of receiving lower levels of pollutants from the airshed, as the pattern of wind circulation maintain them far from the main zones of atmospheric deposition of pollutants. In these lakes, the strongest effects related to environmental change can mainly be attributed to direct and indirect consequences of warming [9], and are mostly related to changes in the permanence of the ice cover both in the lake and the catchment by causing abrupt, threshold-dependent shifts [8]. High Arctic lakes are located in one of the world's stronger warming zones, as well as some polar areas of the southern hemisphere, like the Maritime Antarctic region.

\subsection{Maritime Antarctic lakes}

The Maritime Antarctic region includes the west coast of the Antarctic Peninsula and the associated islands of the Scotia Arc, and extends from the South Sandwich Islands through the South Orkney and South Shetland Islands and down the western side of the Antarctic Peninsula to approximately $72^{\circ} \mathrm{S}$ [10]. Freshwater lakes and ponds in the Maritime Antarctica include, epishelf lakes, and both 


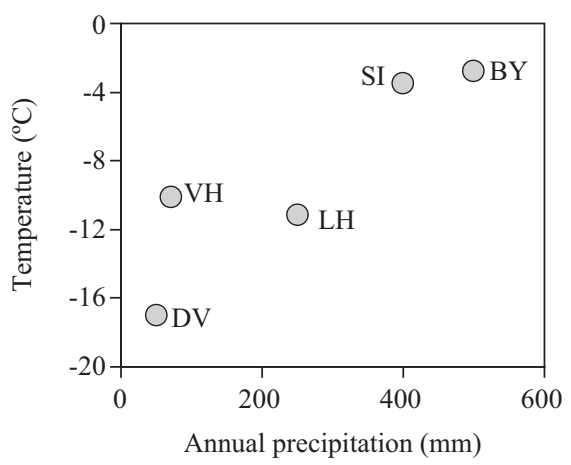

Figure 1: Average yearly temperature and precipitation (snowfall and rainfall) in areas of the Continental Antarctica - DV (Dry Valleys), VH (Vestfold Hills) and LH (Larsemann Hills), and of the Maritime Antarctica - SI (Signy Island) and BY (Byers Peninsula).

deep and shallow inland lakes and ponds lying on rock substrate, as well as coastal lagoons influenced by sea sprays and marine animals $[10,11]$.

All Antarctic lakes can undoubtedly be considered as remote lakes, and except for a few cases they are mostly free from direct pollution and other direct human impacts within their catchments. Consequently, when they are located in areas where acute changes in temperature are occurring, they can also be used as models to study the direct and indirect effects of climate change.

Lakes from continental Antarctica are perennially covered by ice and this ice cover maintains them relatively unaffected by current changes in temperature linked to climate change. Temperatures, in these cases, are always below the freezing point. However, for most lakes from the Maritime Antarctic region and sub-Antarctic islands, environmental conditions are less extreme than in continental Antarctica, and even though average annual temperature is below $0^{\circ} \mathrm{C}$, summer temperatures are commonly over the freezing point, and precipitation is much more abundant than in continental Antarctica (Fig. 1), with a much more active hydrological cycle. Therefore, when the snow cover melts and the lake's ice cap thaws in summer, water flow increases the nutrient circulation in lakes, which in turn favour the development of planktonic and benthic microbial populations. Since quick environmental changes, including an acute warming, are occurring in this region [1, 12], lakes from the Maritime Antarctica and nearby sub-Antarctic islands are suitable for studies of the effect of climate change.

\section{SOME BIOLOGICAL STUDIES ON SUB-ANTARCTIC AND MARITIME ANTARCTIC LAKES}

Although Antarctic freshwater lakes are characterized by short foodwebs dominated by microbes, those from the Maritime Antarctica and sub-Antarctic islands have slightly more complex foodwebs than continental Antarctic lakes, and often include crustacean zooplankton [10]. Among these lakes, special attention has been paid during the last two decades to those from South Georgia, South Orkney Islands, the northern part of the Antarctic Peninsula and the South Shetland Islands. These studies include not only physical and chemical descriptions of the lakes but also the composition of their biological communities and, more interestingly, they developed experimental approaches to reveal biotic interactions and functional processes. 
Hansson and Tranvik (see, e.g. 13), in the 1990s, performed a series of studies in South Georgia's lakes that included experiments in mesocosms, with the manipulation of the presence and/or abundance of consumers, the monitoring of lake's dynamics and the study of the food web using stable isotopes. Interestingly, although somewhat similar in simplicity, the food web of these lakes present an additional trophic level compared to those of lakes from the Maritime Antarctica (which is represented in Fig. 4), with the calanoid copepod Parabroteas sarsi and the diving beetle Lancetes angusticollis as top consumers and shows a higher diversity of metazoan zooplankton than the later. With respect to the functioning of the food web, the main findings of these works were related to the strong effects of size-dependent predation processes, which could extend on cascade through different trophic levels. With respect to primary producers, these authors showed how dominant algae present compensatory mechanisms for predation or morphological features for avoiding predation (big size, spines, mucilage, recruitment from the sediments). Similarly, studies developed on lakes of Signy Island [14, 15], a small sub-Antarctic island from the South Orkney Islands, as well as on lakes of the Antarctic Peninsula [16], showed that grazing could be quite important for the structure and functioning of biological communities in lakes of the region, in spite of the general thought that physical constrains would restrict its relevance. All these findings highlighted the role of biotic interactions, such as predation, as structuring factors for the biological communities of lakes in the area, at least in summer when abiotic restrictions (low temperature and ice-covering of the lakes, low light availability) are less strong than during the rest of the year. Thus, a question raising related to climate change is whether the relevance of these biotic interactions can increase if warming occurs in the area, and if this will also facilitate biological invasions that could further modify the structure of these relatively simple biological communities. To address this question, we have selected as study site, namely, Byers Peninsula, a small area (around $60 \mathrm{Km}^{2}$ ) located in Livingston Island (South Shetland Islands, Maritime Antarctica), which is considered as the richest area in lakes and streams in Antarctica and which is also located within the world's areas experiencing a strongest warming during the last decades [11].

\section{A MODEL STUDY AREA, BYERS PENINSULA, LIVINGSTON ISLAND, SOUTH SHETLAND ISLANDS, MARITIME ANTARCTICA}

Our research in lakes from Byers Peninsula started in 2001, when the Limnopolar research team was created. Since the area is an Antarctic Special Protected Area, permanent facilities cannot be built [17], and a non-permanent camp has been established there from late spring to late summer during most years of the last decade. A meteorological station, located in the main inland lake's area, has been permanently recording meteorological parameters since then. In addition, to our annual expeditions, a multi-national expedition in which scientist from 11 countries participated, was organized coinciding with the International Polar Year from November 2008 to March 2009. This covered most aspects of the physical, chemical and biological features of the aquatic ecosystems of Byers Peninsula as well as other scientific aspects [17].

\subsection{Diversity of freshwater ecosystems in Byers Peninsula}

Byers Peninsula holds a variety of lotic and lenitic ecosystems, which includes short streams and a high number of lakes, ponds and flooded or wet areas. Lakes are found both in the central part of the Peninsula in a plateau of c.a. $100 \mathrm{~m}$ high asl (Fig. 2) and in coastal areas, the later being accessible to marine animals. Lakes from the plateau are located in small catchments on a landform modified 

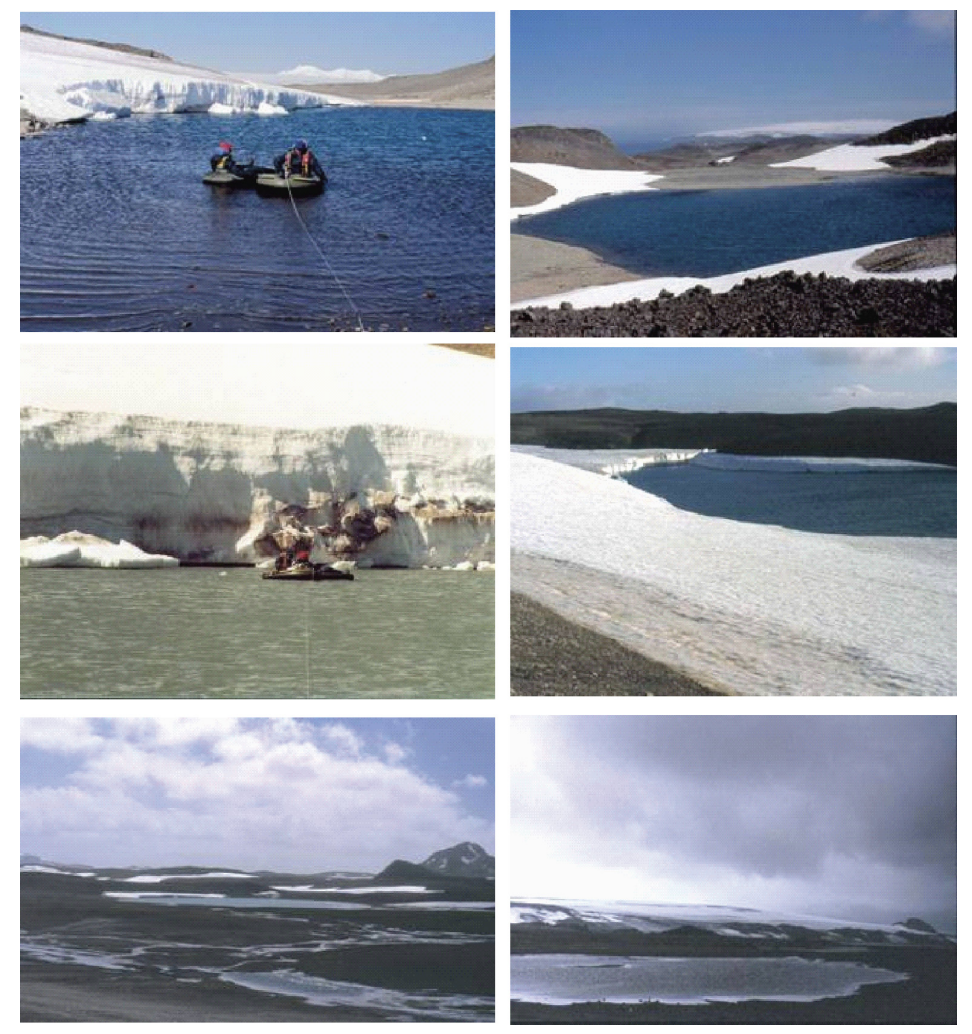

Figure 2: Photographs showing some lakes located in the central plateau of Byers Peninsula.

by fluvial and periglacial processes in terrains favourable for water retention, presenting clear surface outlets. On the other hand, the shallow lagoons located in coastal areas are settled on low relief lands and their surrounding areas may vary from sandy and dry terrains to those largely covered by mosses cushions and plants. Among those sited in the plateau Midge Lake is the deepest $(9 \mathrm{~m})$ and largest water body, although one of them, which we called Lake Limnopolar ( $5 \mathrm{~m}$ depth, 2.2 ha surface), has been selected as a model study lake because it averages the ecological features of most lakes in the plateau well $[11,18]$. Lakes located in the beaches are consistently shallow, with depths around $0.5 \mathrm{~m}$.

The waters of all lakes are lowly mineralized, with lower conductivities (Table 1) occurring in lakes located far from the sea and closest to the glacier front and slightly higher conductivities in coastal lagoons. In accordance with these low conductivities, the content of major ions is relatively low in all lakes, but there is a clear difference in the relative abundance of major ions between lakes from the plateau, mainly those easternmost, and the harder water of coastal lagoons.

Concerning trophic status (see inorganic nutrients and chlorophyll- $a$ (Chl- $a$ ) concentrations in Table 1), most lakes range from ultra-oligotrophic to oligotrophic, except some located close to the coast, in which the influence of marine animals provided high amounts of organic and inorganic nutrients turning on eutrophic conditions [11]. The Chl- $a$ concentrations in lakes situated in the 
Table 1: Ranges and average values (in brackets) for selected variables featuring inland and coastal lakes from Byers Peninsula. DIN: dissolved inorganic nitrogen, SRP: soluble reactive phosphorus, SRSi: soluble reactive silica.

\begin{tabular}{llll}
\hline Variable & \multicolumn{1}{c}{ Unities } & \multicolumn{1}{c}{ Inland lakes } & \multicolumn{1}{c}{ Coastal lagoons } \\
\hline Depth & $\mathrm{m}$ & $0.7-9(4.2)$ & $0.2-0.5(0.4)$ \\
Catchment size & $\mathrm{km}^{2}$ & $0.01-0.58(0.18)$ & $0.12-2.41(1.27)$ \\
Conductivity & $\mu \mathrm{S} \mathrm{cm}{ }^{-1}$ & $20-105(62.5)$ & $90-189(160)$ \\
DIN & $\mu \mathrm{M}$ & $0.4-10.2(3.2)$ & $4.9-49.0(24.3)$ \\
$\mathrm{SRP}$ & $\mu \mathrm{M}$ & $<0.01-0.2(0.08)$ & $0.2-3.1(2.02)$ \\
$\mathrm{SRSi}$ & $\mu \mathrm{M}$ & $2.8-85.3(35.6)$ & $21.3-71.6(46.5)$ \\
Chl- $a$ & $\mu \mathrm{g} \mathrm{l^{-1 }}$ & $0.06-2.22(0.47)$ & $1.44-40.5(19.1)$ \\
Bacterioplankton & $\times 10^{6}$ cells $\mathrm{mL}^{-1}$ & $0.70-4.06(1.39)$ & $3.72-6.58(5.45)$ \\
\hline
\end{tabular}

plateau are also consistently low compared to coastal sites. Bacterial abundances in lakes may vary broadly, showing again a clear difference between inland and coastal water bodies, although they are relatively high in all cases (Table 1). The higher algal and bacterial abundances in the surface waters have been observed at the onset of ice melting linked to increases in nutrients and light availability [19].

\subsection{Most relevant hydrological processes}

Glacier retreat in Byers Peninsula started 4,500 BP, with a considerable part of the Peninsula becoming free of ice in summer about 500 years later [20]. The water retention produced by the ongoing erosion of moraines during the ice withdrawal allowed the gradual formation of many lakes and ponds of different sizes. In Antarctic ice-free areas, such as Byers Peninsula, the functioning of aquatic ecosystems is deeply linked with the surrounding land. Interactions are much restricted during winter by the presence of ice, but, when snow melting occurs, they become more intense, just when biological activity enhances.

The hydrology of lakes in Byers is conditioned by several factors, such as ice and snow melting, rainfall events, surface water evaporation and permafrost dynamics. During summer, the average temperatures are slightly above $0^{\circ} \mathrm{C}$. This proximity to the freezing point makes the lakes very vulnerable to slight changes in temperature. Actually, we have observed remarkable inter-annual variations in the duration of the ice cover in Lake Limnopolar as a function of the air temperature and snow precipitation [19], although complete melting of the ice cover occurs every year (Fig. 3). These variations imply relevant differences in terms of light availability, temperature and water stratification. For instance, the prolongation of the ice-cover period in Lake Limnopolar prevented both evaporation and wind effects, and it allowed for storing of the heat entering into the lake that resulted in a progressive increase of water temperature until ice melting occurred [19].

In lakes from the Continental Antarctica, the homeostasis caused by permanent ice cover results in almost unvarying physical and chemical gradients in lakes [21]. In contrast, in lakes from the Maritime Antarctica, like Lake Limnopolar, during the progress of the summer season, the underwater light regime follows a progressive change towards higher transparency, resulting in higher planktonic 


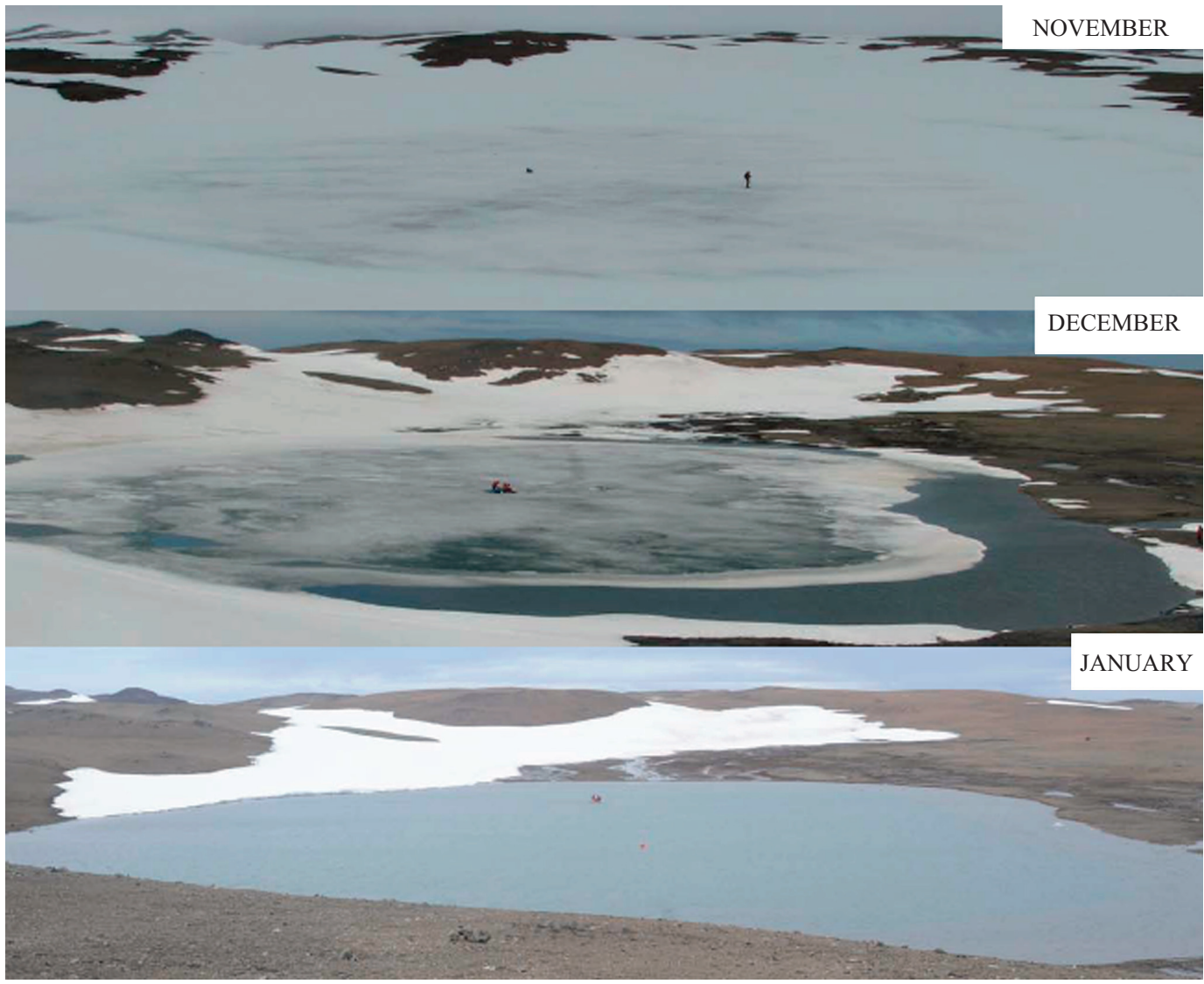

Figure 3: Ice melting process of Lake Limnopolar during the austral spring and summer of 2006-2007.

production just at the onset of ice melting due to increases in nutrients and light availability [19]. Otherwise, the maximum flows in the outlets, which allow the entrance of allochthonous material, occur during snow melt between December and January [11]

\subsection{Biological communities of the lakes}

Lakes from Byers Peninsula show a low biodiversity compared to those of temperate environments, with microbial dominated communities, determined by the environmental hardness. Microbial interactions are then responsible for a large part of energy transfer. Although pelagic primary production is very low; the heterotrophic component of the plankton is relatively abundant for such low productive rates. The nanoplankton is dominated by a small number of flagellated species (both colourless and plastidic forms), small amoebae and ciliates [11]. The phytoplankton populations of lakes are mainly composed of nekton-benthic diatoms, chrysophytes, picocyanobacteria and clorophytes [11], including Prasinophytes [22]. Nevertheless, the lake-to-lake variability on nutrient status also triggers consistent differences of the plankton community structure [11]. The phytobenthos includes 
cyanobacterial mats, epilithic diatoms and the aquatic moss Drepanocladus longifolius forming dense carpets at the bottom of some lakes. Remarkably, a high diversity of viruses has been found in these lakes [22], which also puts the question on the possible regulatory effects of viruses on the planktonic populations of these lakes.

In most lakes of the Maritime Antarctic region, as for those of Byers Peninsula, the copepod Boeckella poppei represents the top consumer of the planktonic food web, being relatively abundant. By contrast, rotifers are generally scarce. More related to benthic habitats, especially in shallower lakes, the fairy shrimp Branchinecta gaini is commonly found. In lakes with a well-developed benthos, two macro-invertebrates, the oligochaete Lumbricillus sp. and the chironomid Parochlus steinenii, may occur closely associated to aquatic mosses [11, 19].

In addition to the biological communities living in the lakes, microbial mats [23] and moss carpets located in the catchments are of high importance for the functioning of the lakes. Moss carpets cover extensively the surroundings of coastal lakes, whereas microbial mats occupy most wet areas of inland lakes.

\subsection{Trophic links and bio-geochemical cycles}

As abovementioned, biological communities of lakes from Byers Peninsula present few species and apparently exhibit simple food webs (Fig. 4), with the copepod Boeckella poppei as the capstone predator. Our data $[10,11,18,19]$ based on observations and experimental manipulations of the communities performed in mesocosms reveal that an efficient top-down control of microbial loop populations may exist, with potential for causing trophic cascades in the microbial pelagic food web of these lakes. This would fit well with the previous findings (see paragraph 3) for sub-Antarctic islands, where climatic restrictions are not so strong. This trophic cascade would be mediated by a strong top-down regulation of protozoa populations by copepods, which indirectly benefits picosized organisms (both autotrophic and heterotrophic). On the other hand, our experimental outcomes support the relevance of nutrient recycling by meta-zooplankton. This will demonstrate that biotic interactions may play a key role on lake functioning despite the supposed strong physical control, at least when physical stressors are temporarily relaxed. On this context, relaxing environmental hardness, as could occur by the acute warming affecting the region, would enhance the relevance of biotic interactions because of the less restrictive conditions and the longer productive (ice-free) periods.

In addition, an important source of allocthonous inputs to lakes can be the benthic communities that flourish in the stream inlets and the surrounding areas of inland lakes (mainly cyanobacterial mats). Microbial mats exudate extracellular polymeric substances (EPS) and dissolved organic carbon (DOC) that may contribute to fuel bacterial production in lakes [23]. Furthermore, an extra supply of nitrogen might come from the activity of the nitrogen-fixing cyanobacteria present in these mats [23]. Also important are the benthic mosses that develop in the bottom of some of the lakes. This benthic cycling of nutrients could be particularly important to feed the whole system (Fig. 4).

\subsection{Temperature dependence of biological activities and food web functioning}

In addition to the study of lakes' dynamics and the interactions of their biotas, our studies also included that of the productive patterns and the specific effects of temperature changes on biotic activities and bio-geochemical processes. As an example, the comparative study of the carbon fixation patterns of two different microbial communities [24], such as those growing on snow compared 


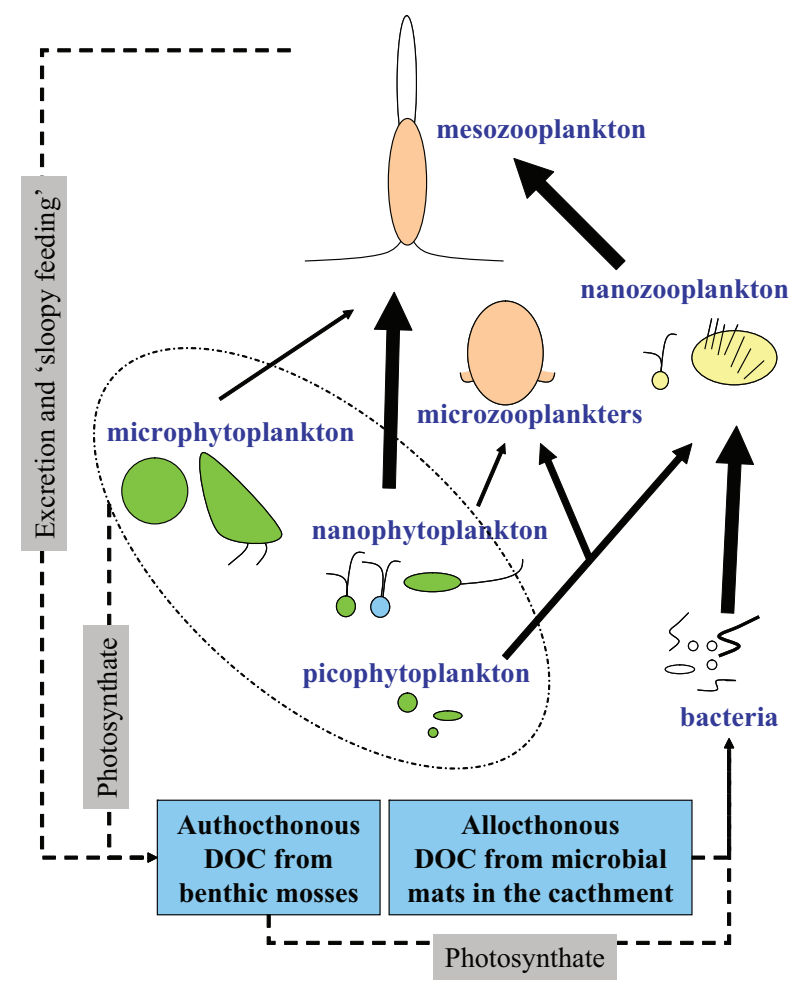

Figure 4: Structure of the food web determined for Lake Limnopolar, a typical inland lake from Maritime Antarctica.

to microbial mats, showed that they have a different nature, from the psychrophilic behaviour of the algae growing on snow to the psychrotolerant but mesophilic patterns shown by microbial mats. Since warming is likely to modify the environmental scenario, with longer snow-free periods during the productive phase (with enough light availability, that is, from late spring to early summer at these latitudes), our results suggest a progressive replacement of communities dominated by psychrophilic micro-organisms by psychrotolerant biota.

All the studies performed by our research group in the model Lake Limnopolar and nearby lakes, together with the studies performed by others authors in sub-Antarctic and Maritime Antarctic lakes, allowed us the recent elaboration of a simple mathematic eco-climatic model to explore the possible effects of temperature changes on the biological assemblages of Lake Limnopolar that integrates in-lake and catchment processes [25]. As a main prognosis, the model predicts that the relevance of biological interactions and bacterial abundance would increase both by the increase in external supplies from benthic communities and by the top-down effects mediated by copepods, which could increase their grazing pressure on nanozooplankters, thus, relaxing the grazing pressure of the later on picoplankton.

\section{BIOLOGICAL INVASIONS}

Antarctic ecosystems may potentially experience the introduction of invasive species. The Antarctic Circumpolar Current provides a long-term isolation of the continent, which could decline due to 
global warming, thus increasing the opportunities for alien species transport and establishment. If climate becomes more favourable for non-indigenous species, some could be able to set up stable populations. In addition, the scarcity of functional groups in freshwater ecosystems may facilitate the success of these invasive species by occupying new ecological niches.

Dispersal of organisms is a function of the connectivity between habitats; therefore, dispersion and successful colonization by alien biota is suitable to be increased especially in the maritime region, where humans are increasing their presence during the last decades, which resulted in the continuous increase of successful invasions by alien species [26]. Indeed, the susceptibility of this region to receive propagules has already been pointed out because of the occurrence of favourable northerly winds [27], but the increased dispersion pathway opened by the enhancement of human visits together with the relaxed climatic hardness caused by regional warming could exponentially increase the chances for biological invasions, which are likely to deeply modify the structure of biological communities and ecosystem functioning. The sub-Antarctic region, which is climatically more moderate compared to other Antarctic regions, has already suffered the invasion of numerous alien species, which compete with the autochthonous biota [26]. So far, the occurrence of alien introductions in the Maritime Antarctica has been, by contrast, much lesser than in the sub-Antarctic region. However, it does occur and could be higher if climate becomes less hard.

\section{CONCLUSIONS AND FORECAST}

Although predictions on the physical effects of regional climate change in Antarctica seem to be confirmed, it is not clear, however, to what extent biological processes will be affected. Likely, the net result in the ecosystem functioning would not be a simple and linear function of warming. Thus, some interactions will have a positive feedback that amplifies environmental changes; by contrast, other might potentially offset the warming effects. Our research suggest that quick environmental changes associated with climate change, which are likely to reduce the strength of physical constraints for life in these Antarctic regions, would potentially increase the role of biotic interactions in structuring Antarctic lake's communities and ecosystem functioning. We predict that bio-geochemical cycles will be more active, ice melting earlier, productive periods longer, primary production higher and the sensitivity to species invasion stronger. In short, something similar to as if the "ecosystems were moving towards north".

\section{REFERENCES}

[1] Solomon, S., Qin, D., Manning, M., Chen, Z., Marquis, M., Averyt, K.B., Tignor, M. \& Miller H.L., (eds.). Climate change: the physical science basis. Contribution of Working Group I to the 4th Assessment Report of the Intergovernmental Panel on Climate Change. Cambridge Univ. Press, 2007.

[2] MacKay, M.D., Neale, P.J., Arp, C.D., De Senerpont Domis, L.N., Fang, X., Gal, G., Johnk, K.D., Kirillin, G., Lenters, J.D., Litchman, E., MacIntyre, S., Marsh, P., Melack, J., Mooij, W.M., Peeters, F., Quesada, A., Schladow, S.G., Schmid, M., Spence, C. \& Stokes, S.L., Modeling lakes and reservoirs in the climate system. Limnology and Oceanography, 54(6), pp. 2315-2329, 2009. doi: http://dx.doi.org/10.4319/lo.2009.54.6 part 2.2315

[3] Williamson, C.E., Saros, J.E., Vincent, W.F. \& Smol, J.P. Lakes and reservoirs as sentinels, integrators, and regulators of climate change. Limnology and Oceanography, 54(6), pp. 22732282, 2009. doi: http://dx.doi.org/10.4319/lo.2009.54.6 part 2.2273

[4] Adrian, R., O'Reilly, C.M., Zagarese, H., Baines, S.B., Hessen, D.O., Keller, W., Livingstone, D.M., Sommaruga, R., Straile, D., Van Donk, E., Weyhenmeyer, G.A. \& Winder M., Lakes as 
sentinels of climate change. Limnology and Oceanography, 54(6), pp. 2283-2297, 2009. doi: http://dx.doi.org/10.4319/lo.2009.54.6 part 2.2283

[5] Catalan, J., Camarero, L., Felip, M., Pla, S., Ventura, M., Buchaca, T., Bartumeus, F., de Mendoza, G., Miro, A., Casamayor, E.O., Medina-Sanchez, J.M., Bacardit, M., Altuna, M., Bartrons, M. \& Diaz de Quijano, D., High mountain lakes: extreme habitats and witnesses of environmental change. Limnetica, 25(1-2), pp. 551-584, 2006.

[6] Battarbee, R.W., Mountain lakes, pristine or polluted? Limnetica, 24(1-2), pp. 1-8, 2005.

[7] Mladenov, N., Sommaruga, R., Morales-Baquero, R., Laurion, I., Camarero, L., Dieguez, M.C., Camacho, A., Delgado, A, Torres, O., Chen, Z. \& Reche, I., Dust inputs and bacteria influence dissolved organic matter in clear alpine lakes. Nature Communications, 2, 405 doi:10.1038/comms1411, 2011. doi: http://dx.doi.org/10.1038/comms1411

[8] Mueller, D.R., Van Hove, P., Antoniades, D., Jeffries, M.O. \& Vincent, W.F., High Arctic lakes as sentinel ecosystems: Cascading regime shifts in climate, ice cover, and mixing. Limnology and Oceanography, 54(6), pp. 2371-2385, 2009. doi: http://dx.doi.org/10.4319/lo.2009.54.6 part 2.2371

[9] Agusti, S., Sejr, M.K. \& Duarte, C.M., Impacts of climate warming on polar marine and freshwater ecosystems. Polar Biology, 33(12), pp. 1595-1598, 2010. doi: http://dx.doi.org/10.1007/ $\underline{\mathrm{S} 00300-010-0955-0}$

[10] Camacho., A., Planktonic microbial assemblages and the potential effects of metazooplankton predation on the food web of lakes from the Maritime Antarctica and sub-Antarctic islands. Reviews on Environmental Science and Biotechnology, 5, pp. 167-185, 2006. doi: http://dx.doi. org/10.1007/s11157-006-0003-2

[11] Toro, M., Camacho, A., Rochera, C., Rico, E., Banon, M., Fernandez-Valiente, E., Marco, E., Justel, A., Vincent, W.F., Avendano, M.C., Ariosa, Y. \& Quesada, A., Limnological characteristics of the freshwater ecosystems of Byers Peninsula, Livingston Island, in Maritime Antarctica. Polar Biology, 30(5), pp. 635-649, 2007. doi: http://dx.doi.org/10.1007/s00300006-0223-5

[12] Quayle, W.C, Peck, L.S., Peat, H., Ellis-Evans, J.C. \& Harrigan, P.R., Extreme responses to climate change in Antarctic lakes. Science, 295, p. 645. 2002. doi: http://dx.doi.org/10.1126/ science. 1064074

[13] Hansson, L.-A. \& Tranvik, L., Quantification of invertebrate predation and herbivory in food webs of low complexity. Oecologia, 108(3), pp. 542-551, 1996. doi: http://dx.doi.org/10.1007/ BF00333732

[14] Butler, H., Atkinson, A. \& Gordon, M., Omnivory and predation impact of the calanoid copepod Boeckella poppei in a Maritime Antarctic lake. Polar Biology, 28(11), pp. 815-821, 2005. doi: http://dx.doi.org/10.1007/s00300-005-0014-4

[15] Laybourn-Parry J., Ellis-Evans, J.C. \& Butler, H., Microbial dynamics during the summer iceloss phase in maritime Antarctic lakes. Journal of Plankton Research, 18(4), pp. 495-511, 1996. doi: http://dx.doi.org/10.1093/plankt/18.4.495

[16] Almada, P., Allende L., Tell G. \& Izaguirre I., Experimental evidence of the grazing impact of Boeckella poppei on phytoplankton in a maritime Antarctic lake. Polar Biology, 28(1), pp. 39-46, 2004

[17] Quesada, A., Camacho, A., Rochera, C. \& Velazquez, D., Byers Peninsula: A reference site for coastal, terrestrial and limnetic ecosystem studies in maritime Antarctica. Polar Science, 3(3), 181-187, 2009. doi: http://dx.doi.org/10.1016/j.polar.2009.05.003

[18] Villaescusa, J.A., Casamayor, E.O., Rochera, C., Velazquez, D., Chicote, A., Quesada, A. \& Camacho, A., A close link between bacterial community composition and environmental heterogeneity in maritime Antarctic lakes. International Microbiology, 13(2), 67-77, 2010. 
[19] Rochera, C., Justel, A., Fernandez-Valiente, E., Banon, M., Rico, E., Toro, M., Camacho, A. \& Quesada, A., Interannual meteorological variability and its effects on a lake from maritime Antarctica. Polar Biology, 33(12), pp. 1615-1628, 2010. doi: http://dx.doi.org/10.1007/ $\underline{\mathrm{s} 00300-010-0879-8}$

[20] Bjorck, S., Olsson, S., Ellis-Evans, C., Hakansson, H., Humlum, O. \& De Lirio, J.M., Late Holocene palaeoclimatic records from lake sediments on James Ross Island, Antarctica. Palaeogeography, Palaeoclimatology, Palaeoecology, 121(3-4), pp.195-220, 1996. doi: http:// dx.doi.org/10.1016/0031-0182(95)00086-0

[21] Spigel, R.H. \& Priscu, J.C., Physical limnology of the McMurdo Dry Valley lakes (Chapter 3). Ecosystem dynamics in a Polar Desert: the McMurdo Dry Valleys, Antarctica, ed. J.C. Priscu, American Geophysical Union, Washington DC, pp 153-189, 1998.

[22] Lopez-Bueno, A., Tamames, J., Velazquez, D., Moya, A., Quesada, A. \& Alcami, A., High diversity of the viral community from an Antarctic lake. Science, 326, pp. 858-861, 2009. doi: http://dx.doi.org/10.1126/science.1179287

[23] Fernandez-Valiente, E., Camacho, A., Rochera, C., Rico, E., Vincent, W.F. \& Quesada, A., Community structure and physiological characterization of microbial mats in Byers Peninsula, Livingston Island (South Shetland Islands, Antarctica). FEMS Microbiology Ecology, 59(2), 377-385, 2007. doi: http://dx.doi.org/10.1111/j.1574-6941.2006.00221.x

[24] Velazquez, D., Rochera, C., Camacho, A. \& Quesada, A., Temperature effects on carbon and nitrogen metabolism in some Maritime Antarctic freshwater phototrophic communities. Polar Biology, 34(7), pp. 1045-1055, 2011. doi: http://dx.doi.org/10.1007/s00300-011-0964-7

[25] Villaescusa, J.A., Jørgensen, S.E., Rochera, C., Velazquez, D., Quesada, A. \& Camacho, A., Carbon flow modelization of the microbial planktonic foodweb in an oligotrophic freshwater Antarctic lake. Submitted to Ecological Modeling.

[26] Frenot, Y., Chown, S.L., Whinam, J., Selkirk, P.M., Convey, P., Skotnici, M. \& Bergstrom, D.M., Biological invasions in the Antarctic: Extent, impacts and implications. Biological Reviews, 80(1), pp. 45-72, 2005. doi: http://dx.doi.org/10.1017/S1464793104006542

[27] Ellis-Evans, J.C. \& Walton, D., The process of colonization in Antarctic terrestrial and freshwater ecosystems. Proceedings of the National Institute of Polar Research Symposium on Polar Biology, 3, pp. 151-163, 1990. 